\title{
Collagenase as an agent for dissolving the zona pellucida of hamster and mouse oocytes
}

\author{
M. Zuccotti ${ }^{1 *}$, U. A. Urch ${ }^{2}$ and R. Yanagimachi ${ }^{1} \dagger$ \\ ${ }^{1}$ Department of Anatomy and Reproductive Biology, University of Hawaii School of Medicine, \\ Honolulu, Hawaii 96822, USA and ${ }^{2}$ Department of Biochemistry and Biophysics, University of \\ California, Davis, CA 95616, USA
}

\begin{abstract}
Summary. Crude preparations of collagenase, which have been used commonly for tissue dissociation, contain proteases that dissolve zonae pellucidae of hamster and mouse oocytes without reducing the ability of the oolemma to fuse with spermatozoa. This gentle proteolytic removal of zona is particularly useful for the study of spermoocyte fusion in mice, as trypsin, chymotrypsin and pronase damage the mouse oolemma.
\end{abstract}

Keywords: collagenase; zona pellucida; oocyte; spermatozoa; fusion; mouse; hamster

\section{Introduction}

The outer glycoprotein envelope of mature mammalian oocytes, the zona pellucida, plays a number of important roles in fertilization and development, including the induction of the acrosome reaction of spermatozoa immediately before fertilization (Wassarman, 1987; Yanagimachi, 1988a; Kopf \& Gerton, 1991), but the zona pellucida is not essential for fertilization. Normal, monospermic fertilization can occur when zona-free oocytes are inseminated carefully in vitro with spermatozoa that have undergone the acrosome reaction either spontaneously or in response to various biological and chemical reagents (Thadani, 1982; Boldt \& Wolf, 1986; Kamiguchi \& Mikamo, 1986). Use of zona-free oocytes is advantageous to the study of sperm-oocyte fusion, because the time of sperm-oocyte contact and fusion can be determined much more precisely than with the insemination of zona-intact oocytes, in which the time required for passage of spermatozoa through the zona is variable (Yanagimachi, 1988b; Tesarik \& Kopecny, 1989).

Zonae can be removed either mechanically or chemically. Mechanical removal by blowing oocytes in and out of a small-bore pipette is believed to be the least traumatic to oocytes, but it is difficult to achieve. Even in skilful hands, many oocytes degenerate during and after processing. Damage to the plasma membrane (oolemma) of many oocytes seems to be inevitable. Although the enzymatic method is much more efficient than the mechanical approach, enzymes may alter the biochemical and biological characteristics of the oolemma. For example, a 30-min treatment of the mouse oolemma with $0.01 \%$ pronase or chymotrypsin severely reduces its ability to fuse with spermatozoa (Wolf et al., 1976). We report here that a commercially available preparation of collagenase, which has been used commonly for tissue dissociation, contains proteases that gently dissolve zonae of mouse and hamster oocytes without reducing fusibility of the oolemma.

\section{Materials and Methods}

Animals. The female and male golden Syrian hamsters used in this study were 2-4 and 4-6 months old, respectively. Mice (B6CBAF $1 /$; Jackson Laboratory, Bar Harbor, ME, USA) were 2-4 months old.

*Present address: Dipartimento Biologia Animale, Universita degli Studi di Pavia, Pavia, Italy.

$\uparrow$ Reprint requests. 
Chemicals. All chemicals, including collagenase, were purchased from Sigma Chemical Co. (St Louis, MO, USA) unless otherwise stated. Protein was assayed with the BCA method (Pierce Chemical Co., Rockford, IL, USA) using bovine serum albumin as a standard.

Enzyme assays. Assays for protease activities were performed using methyl coumarin (MCA) substrates and involved measuring the release of 7-amino-4-methyl-coumarin (AMC) fluorimetrically at excitation/emission maxima of 380 and $460 \mathrm{~nm}$, respectively, and converting the increase in fluorescence units to nmoles of AMC formed. The following enzymes were assayed with MCA substrates (Peptides International, Louisville, KY, USA): collagenase 1 or clostripeptidase was assayed with succinyl-gly-pro-leu-gly-pro-MCA; trypsin-like enzymes, including clostripain, with BOC-leu-thr-arg-MCA; elastase with succinyl-ala-pro-ala-MCA; chymotrypsin with succinyl-ala-ala-pro-phe-MCA; and leucine aminopeptidase with leu-MCA.

In the specific assays methods, 5-20 $\mu \mathrm{l}$ of unknown material was added to $0.125 \mu \mathrm{mol}$ of the test MCA (dissolved in dimethyl sulphoxide-DMSO) $/ 1$ in $50 \mathrm{mmol}$ TES/l containing $0.36 \mathrm{mmol} \mathrm{CaCl}_{2} / 1, \mathrm{pH} 7.5$, and the increase in fluorescence was measured. For collagenase I, the coupled enzyme assay of Kojima et al. (1979) was used as follows: 5-20 $\mu \mathrm{l}$ of the sample was added to $0.8 \mathrm{mmol}$ succinyl-gly-pro-leu-gly-pro-MCA (dissolved in DMSO)/l, in TES buffer, for $30 \mathrm{~min}$ at $37^{\circ} \mathrm{C}$. The assay was stopped by boiling for $5 \mathrm{~min}$ and $5 \mu \mathrm{l}$ of $0.02 \mu \mathrm{g}$ cathepsin $/ \mu \mathrm{l}$ in assay buffer was added to hydrolyse the gly-pro-MCA formed by collagenase I. This was incubated for $30 \mathrm{~min}$ at $37^{\circ} \mathrm{C}$, and the AMC was then measured fluorimetrically. One unit of MCA activity is defined as the production of 1 nmol of AMC produced/min.

Enzyme purification. The trypsin-like activity in the crude collagenase preparation was separated from collagenase I by affinity purification on immobilized $p$-aminobenzamidine (Pierce Chemical Co.). This separation was performed by dissolving $49 \mathrm{mg}$ crude collagenase in $2.5 \mathrm{ml}$ of $50 \mathrm{mmol} \mathrm{TES} / \mathrm{l}, 0.36 \mathrm{mmol} \mathrm{CaCl}_{2} / \mathrm{l}, \mathrm{pH} 7.5$, mixing the solution with a suspension of immobilized $p$-aminobenzamidine and pouring the suspension into a plastic column (Econo column $1.5 \times 9 \mathrm{~cm}$, BioRad, Richmond, CA, USA). The column was washed with five volumes of dissolution buffer

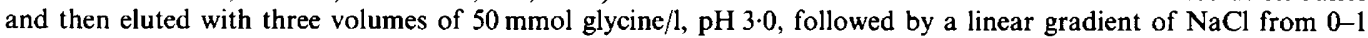
$\mathrm{mol} / \mathrm{l}$, in the dissolution buffer. Fractions of $1 \mathrm{ml}$ were collected automatically and assayed for MCA activities.

Sigma type II collagenase is a mixture of proteases that is specified to contain $530 \mathrm{U}$ collagenase digestion $\mathrm{U} / \mathrm{mg}$, $29 \mathrm{U} \mathrm{FC}$ neutral protease/mg and $1.0 \mathrm{U}$ BAEE/mg clostripain. When this crude preparation was assayed for MCA activities (above), $1 \mathrm{mg}$ contained $909 \mathrm{U}$ of collagenase I (or clostripeptidase) activity, $360 \mathrm{U}$ of trypsin-like (including collagenase II or clostripain) activity and $52 \mathrm{U}$ of chymotrypsin activity. Passing this preparation over an immobilized $p$-aminobenzamidine column increased the collagenase I (clostripeptidase) activity to $2276 \mathrm{U} / \mathrm{mg}$, while removing most of the trypsin-like activities ( $7 \mathrm{U} \mathrm{MCA} / \mathrm{mg}$ ).

Media. The medium used for the induction of capacitation and acrosome reaction of hamster and mouse spermatozoa was a modified Tyrode's solution, mTALP-3, with the following composition: $101.02 \mathrm{mmol} \mathrm{NaCl}$, $2.68 \mathrm{mmol} \mathrm{KCl}, 1.80 \mathrm{mmol} \mathrm{CaCl}_{2}, 0.49 \mathrm{mmol} \mathrm{MgCl}_{2}, 0.36 \mathrm{mmol} \mathrm{NaH} \mathrm{PO}_{4}, 35.70 \mathrm{mmol} \mathrm{NaHCO}, 4.50 \mathrm{mmol}$ glucose, $1.0 \mathrm{mmol}$ sodium pyruvate, $9.0 \mathrm{mmol}$ sodium lactate, $0.5 \mathrm{mmol}$ hypotaurine, $0.05 \mathrm{mmol}(-)$ adrenaline and $0.1 \mathrm{mmol}$ EDTA all per 1 and $15 \mathrm{mg}$ bovine serum albumin (BSA, Fr. V., Calbiochem, La Jolla, CA, USA)/ml and $50 \mu \mathrm{g}$ gentamicin sulphate $/ \mathrm{ml}$. A modified Krebs-Ringer solution (Inoue \& Wolf, 1975-IW medium) containing $4 \mathrm{mg} \mathrm{BSA} / \mathrm{ml}$ was used for enzyme treatment and insemination. The $\mathrm{pH}$ of mTALP-3 and IW medium was adjusted to $7 \cdot 4$ after equilibration under $5 \% \mathrm{CO}_{2}$ in air.

Preparation of spermatozoa. Hamster spermatozoa were allowed to undergo capacitation and acrosome reaction according to the method of Zuccotti et al. (1991). Cauda epididymidal spermatozoa were allowed to swim up into mTALP-3 medium, and the medium $(0.3 \mathrm{ml})$ containing actively motile spermatozoa $\left(2-3 \times 10^{6} \mathrm{cells} / \mathrm{ml}\right)$ was incubated for $4-5 \mathrm{~h}$ at $37^{\circ} \mathrm{C}$ under mineral oil (Squibb \& Sons, Princeton, NJ, USA) in a plastic Petri dish $(30 \times 10 \mathrm{~mm}$, Oxnard, CA, USA). At the end of this incubation, $40-50 \%$ of spermatozoa was acrosome-reacted and actively motile. Mouse spermatozoa $\left(\sim 5 \times 10^{6}\right.$ cells $\left./ \mathrm{ml}\right)$ were similarly incubated in mTALP-3 medium, but for only $2 \mathrm{~h}$.

Collection of oocytes and removal of zonae pellucidae. Oocytes were recovered from oviducts of superovulated animals between 15 and $17 \mathrm{~h}$ (hamster) or at $\sim 15 \mathrm{~h}$ (mouse) after injection of human chorionic gonadotrophin (Inoue \& Wolf, 1975; Hirao \& Yanagimachi, 1978). The oocyte-cumulus complex was treated for 10 min with $0 \cdot 1 \%$ bovine testicular hyaluronidase ( 300 U USP/mg; ICN Biochemicals, Costa Mesa, CA, USA) to disperse cumulus cells. Cumulus-free oocytes thus obtained were thoroughly rinsed with IW medium before zonae were removed. Zonae of some hamster and mouse oocytes were removed by mechanical means (pipetting oocytes in and out of a small-bore pipette) as described by Wolf et al. (1976); $\sim 30 \%$ of the oocytes survived, the remainder were cytolysed during or after manipulation. Zonae of hamster and mouse oocytes were also removed by the enzymes trypsin (bovine pancreatic, $2 \times$ cryst., $3000 \mathrm{U} \mathrm{NF} / \mathrm{mg}$; ICN), bovine pancreatic $\alpha$-chymotrypsin $(3 \times$ cryst., $45 \mathrm{U} \mathrm{BTEE} / \mathrm{mg}$, Sigma) and collagenase (from Clostridium histolyticum, type II, $530 \mathrm{U} \mathrm{CD/mg,} \mathrm{Sigma).} \mathrm{Each} \mathrm{enzyme} \mathrm{was} \mathrm{dissolved} \mathrm{in} \mathrm{IW} \mathrm{medium}$ immediately before use. The collagenase preparation contained some insoluble material and so was filtered $(0 \cdot 45 \mu \mathrm{m})$ before use. All zona-free oocytes were rinsed thoroughly and kept in IW medium for 15-30 min before insemination.

Insemination and examination of oocytes. Zona-free oocytes were put in $0.3 \mathrm{ml}$ of $\mathrm{IW}$ medium, which had been previously placed under mineral oil in a plastic Petri dish. Insemination was performed by adding $10 \mu l$ of preincubated sperm suspension to the drop of IW medium containing oocytes. The final concentration of live spermatozoa in the insemination medium was $2-5 \times 10^{4} \mathrm{cells} / \mathrm{ml}$. Inseminated oocytes were incubated at $37^{\circ} \mathrm{C}$ for $1 \mathrm{~h}$ before they were removed from the dish, mounted between a slide and coverslip and examined with a phase-contrast microscope 
for evidence of fertilization. An oocyte was recorded as fertilized when at least one decondensing sperm head (nucleus) or sperm pronucleus with associated tail was discernible within the ooplasm. Results were analysed using Student's $t$ tests.

\section{Results}

\section{Removal (dissolution) of hamster and mouse zonae pellucidae by enzymes}

Hamster zonae were rapidly dissolved by trypsin and $\alpha$-chymotrypsin. At $25-30^{\circ} \mathrm{C}, 0 \cdot 1$ and $0.05 \%$ solutions of trypsin $(=3000 \mathrm{U} \mathrm{NF} / \mathrm{ml}$ and $1500 \mathrm{U} \mathrm{NF} / \mathrm{ml}$, respectively) dissolved zonae completely in $2-2.5$ and $3.5-4 \mathrm{~min}$, respectively. Chymotrypsin $(0 \cdot 05-0 \cdot 1 \%$ or $27-45 \mathrm{U} \mathrm{BTEE} / \mathrm{ml})$ took $<1 \mathrm{~min}$, while $0.25 \%$ solution of crude collagenase (1325 U CD/ml) took 6-7 min to dissolve zonae completely. Unlike trypsin and chymotrypsin, the zona-dissolving action of collagenase ( $825 \mathrm{U} \mathrm{CD} / \mathrm{ml})$ was inhibited by EDTA $(2.7 \mathrm{mmol} / \mathrm{l})$, but not by PMSF $(2 \mathrm{mmol} / \mathrm{l})$, TLCK $(2 \mathrm{mmol} / \mathrm{l})$, soya bean trypsin inhibitor $(2.5 \mathrm{mg} / \mathrm{ml})$ or aprotinin $(2 \cdot 5 \mathrm{mg} / \mathrm{ml})$.

When mouse oocytes were exposed to $0.001 \%(=0.45 \mathrm{U} \mathrm{BTEE} / \mathrm{ml})$ chymotrypsin for 3-9 $\mathrm{min}$, $60-80 \%$ of the zonae expanded (swelled) and were removable by gentle pipetting, as reported by Boldt \& Wolf (1986). The remaining zonae did not respond to this treatment. When mouse oocytes were exposed to $0 \cdot 25 \%(=1325 \mathrm{U} \mathrm{CD} / \mathrm{ml})$ of crude collagenase for $6-9 \mathrm{~min}, 50 \%$ of the zonae disappeared, the remainder expanded and $70-80 \%$ of these were removed by subsequent gentle pipetting. Thus, altogether, $80-90 \%$ of collagenase-treated mouse oocytes became zona-free.

When collagenase I (clostripeptidase) was separated from clostripain and other trypsin-like activity by affinity chromatography, it failed to dissolve hamster and mouse zonae at $2.5 \mathrm{mg} / \mathrm{ml}$ or $5690 \mathrm{U} \mathrm{MCA} / \mathrm{ml}$.

Table 1. Capacity for fertilization of hamster and mouse oocytes freed from zonae pellucidae by various methods

\begin{tabular}{|c|c|c|c|}
\hline $\begin{array}{l}\text { Method of } \\
\text { zona removal }\end{array}$ & $\begin{array}{c}\text { No. of } \\
\text { oocytes } \\
\text { inseminated }\end{array}$ & $\begin{array}{l}\% \text { oocytes } \\
\text { fertilized }\end{array}$ & $\begin{array}{l}\text { Mean no. }( \pm \text { s.d. }) \text { of } \\
\text { decondensed sperm } \\
\text { nuclei/oocyte* }\end{array}$ \\
\hline \multicolumn{4}{|l|}{ Hamster } \\
\hline Pipetting & 18 & 100 & $7 \pm 2 \cdot 6^{\mathrm{a}}$ \\
\hline $\begin{array}{l}\text { Trypsin } \\
\quad(0 \cdot 1 \%, 2-3 \mathrm{~min})\end{array}$ & 35 & 100 & $7 \pm 2 \cdot 9^{a}$ \\
\hline $\begin{array}{l}\text { Chymotrypsin } \\
(0 \cdot 1 \%, 2-3 \mathrm{~min})\end{array}$ & 37 & 100 & $7 \pm 2 \cdot 7^{a}$ \\
\hline $\begin{array}{l}\text { Collagenase } \\
\quad(0.25 \%, 6-9 \mathrm{~min})\end{array}$ & 42 & 100 & $8 \pm 3 \cdot 5^{a}$ \\
\hline \multicolumn{4}{|l|}{ Mouse } \\
\hline Pipetting only & 12 & 100 & $1 \pm 0 \cdot 5^{b}$ \\
\hline $\begin{array}{l}\text { Chymotrypsin } \\
\text { (0.001\%,6-9 min) } \\
\text { + pipetting }\end{array}$ & 34 & 87 & $2 \pm 1 \cdot 8^{b \cdot c}$ \\
\hline $\begin{array}{l}\text { Collagenase } \\
(0 \cdot 25 \%, 6-9 \mathrm{~min}) \\
\text { alone or collagenase } \\
\text { + pipetting }\end{array}$ & 36 & 100 & $7 \pm 2 \cdot 5^{c}$ \\
\hline
\end{tabular}

${ }^{*}$ Determined $\sim 1 \mathrm{~h}$ after insemination.

${ }^{2}$ No significant differences among the 4 groups: $P>0 \cdot 1$.

${ }^{b}$ No significant difference between pipetting only and chymotrypsin-pipetting treatment groups: $P>0 \cdot 1$.

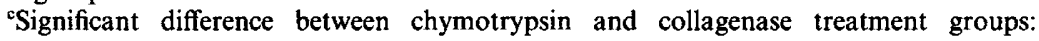
$P<0.001$.

Number of replicates $=4$. 


\section{Capacity of zona-free oocytes for fertilization}

When hamster oocytes were rendered zona-free, by either mechanical or enzymatic methods, and inseminated, they were all fertilized (Table 1). The mean number of spermatozoa fused with each oocyte was $7-8$. When mouse oocytes were inseminated after removal of zonae by pipetting only, or by a combination of chymotrypsin and pipetting, only $\sim 1-2$ spermatozoa fused with each oocyte (Table 1). In contrast, an average of 7 spermatozoa fused with each oocyte when zonae were removed with collagenase alone or collagenase plus pipetting (Table 1). To determine the cause of this difference, oocytes were sequentially treated with collagenase and chymotrypsin or vice versa. The results (Table 2) indicate that collagenase does not affect the fusibility of the oolemma, whereas chymotrypsin reduces it rapidly.

Table 2. Capacity for fertilization of zona-free mouse oocytes treated with collagenase or $\alpha$-chymotrypsin

\begin{tabular}{|c|c|c|c|}
\hline \multicolumn{2}{|c|}{ Enzyme treatments } & \multirow{2}{*}{$\begin{array}{c}\text { No. of oocytes } \\
\text { inseminated } \\
\text { (\% fertilized) }\end{array}$} & \multirow{2}{*}{$\begin{array}{c}\text { Mean no. }( \pm \text { s.d. }) \\
\text { of decondensed } \\
\text { sperm nuclei/oocyte }\end{array}$} \\
\hline $\begin{array}{l}\text { First } 10 \mathrm{~min} \\
\text { (zona removal) }(\%)\end{array}$ & $\begin{array}{l}\text { Next } 15 \min \\
(\%)\end{array}$ & & \\
\hline \multicolumn{4}{|l|}{ Collagenase } \\
\hline 0.25 & - & $19(100)$ & $5 \cdot 6 \pm 1 \cdot 2^{a, c}$ \\
\hline 0.25 & Collagenase 0.25 & $15(100)$ & $5 \cdot 9 \pm 1 \cdot 2^{\mathrm{a}, \mathrm{b}}$ \\
\hline $0 \cdot 25$ & Chymotrypsin 0.001 & $18(22)$ & $0.2 \pm 0.2^{b}$ \\
\hline \multicolumn{4}{|l|}{ Chymotrypsin } \\
\hline $0.001^{*}$ & - & $20(100)$ & $1 \cdot 2 \pm 0 \cdot 7^{\mathrm{c}, \mathrm{d}}$ \\
\hline $0.001^{*}$ & Chymotrypsin $0 \cdot 001$ & $12(50)$ & $0.6 \pm 0 \cdot 8^{e, f}$ \\
\hline $0 \cdot 100 \dagger$ & Chymotrypsin $0 \cdot 100$ & $20(10)$ & $0 \cdot 1 \pm 0 \cdot 1^{\mathrm{e}}$ \\
\hline $0.001 *$ & Collagenase 0.250 & $18(100)$ & $1 \cdot 0 \pm 0 \cdot 6^{\mathrm{d}, \mathrm{f}}$ \\
\hline
\end{tabular}

*Zonae that were swollen after 10 min chymotrypsin treatment were removed by pipetting before further treatment.

†Zonae of $\sim 50 \%$ of oocytes were removed by 10 min chymotrypsin treatment; swollen zonae of remaining oocytes were removed by subsequent pipetting; all zona-free oocytes were combined before further treatment with chymotrypsin.

${ }^{a, d, f}$ No significant differences between the 2 groups: $P>0 \cdot 1$.

b.c.e Significant differences exist between the 2 groups: $P<0.05$.

Number of replicates $=4$.

\section{Discussion}

For analytical studies of sperm-oocyte fusion, it is desirable to remove zonae pellucidae from oocytes before insemination. Almost any protease can be used to remove zonae from hamster oocytes because they do not impair the fusibility of the oolemma (Hirao \& Yanagimachi, 1978; Table 1 of this study). The oolemma of hamster oocytes remains capable of fusing with spermatozoa even after extensive treatment with such a powerful enzyme as pronase (Hirao \& Yanagimachi, 1978). Unlike the hamster oolemma, the mouse oolemma is vulnerable to protease. For example, a 30 -min treatment of mouse oocytes with $0.1 \% \alpha$-chymotrypsin or trypsin renders most of them incapable of fusing with spermatozoa (Boldt \& Wolf, 1986; Boldt et al., 1988). According to Boldt et al. (1989), chymotrypsin removes a $94-\mathrm{kDa}$ protein, which is believed to be important for sperm-oocyte fusion, from mouse oolemma. Therefore, trypsin and chymotrypsin must be used carefully in removing zonae from mouse oocytes. Boldt \& Wolf (1986) recommended a combined enzymatic (a brief treatment of oocytes with $\alpha$-chymotrypsin) and mechanical (pipetting) procedure to obtain zona-free mouse oocytes for the study of sperm-oocyte fusion. Although the 
oocytes thus obtained were as fertile as the oocytes freed from the zonae by mechanical means, they showed less capacity for fusion with spermatozoa than those denuded by collagenase (Table 1). Chymotrypsin reduced the fertility of mouse oocytes: the longer the exposure to this enzyme the less fertile the oocytes (Table 2). It seemed that the crude collagenase we used maintained the fertility of the oocytes, rather than increasing it. Contrary to the general belief that mechanical removal of the zona is least traumatic to the oocytes, in our experiments they were obviously damaged, as shown by cytolysis in most after mechanical denudation. Although surviving oocytes appeared normal and were fertilizable, their oolemmae could have been damaged considerably. Thus, collagenase, which maintains fusibility of the mouse oolemma, would be a safer enzyme for removing zonae from mouse oocytes. If the concentration of spermatozoa in the insemination medium had been carefully controlled, polyspermic fertilization as reported in this study (Tables 1 and 2) could have been avoided.

Commercially available collagenase, prepared from Clostridium histolyticum, contains collagenase I or clostripeptidase, a mixture of trypsin-like proteases that include collagenase II or clostripain and leucine aminopeptidase. Collagenase $I$ is a unique protease that specifically hydrolyses the $\mathrm{Y}$-gly bond in the amino acid sequence -pro-Y-gly-pro- of collagen (where $\mathrm{Y}$ is most frequently a neutral amino acid). To degrade and dissolve collagen fibrils completely, this enzyme requires the assistance of other proteases. In this study, we reported that a crude collagenase preparation could dissolve hamster and mouse zonae. It could also dissolve rat zonae, but not guinea-pig, bovine or human zonae (R. Yanagimachi, T. T. F. Huang \& M. Zuccotti, unpublished observations). EDTA, which inhibits both of the major proteases (clostripeptidase and clostripain) in collagenase preparation, inhibited zona dissolution, while other protease inhibitors had no effect. When most of the clostripain and other trypsin-like proteases were removed by affinity chromatography from the crude collagenase preparation, the remaining collagenase did not dissolve hamster or mouse zona. Crude collagenase preparations have been used to prepare large quantities of porcine zonae, without apparent dissolution (Gwatkin et al., 1980), although Hedrick \& Wardrip (1986) subsequently showed that the zona was hydrolysed extensively, with the loss of the $90-\mathrm{kDa}$ component of the $90-\mathrm{kDa}$ family and the reduction in molecular mass of other zona components. Boar sperm acrosin also does not dissolve porcine zonae, even though acrosin extensively hydrolyses zona glycoproteins to very small glycopeptides, which continue to interact (Urch, 1991). Although no dissolution was observed, collagenase I may have hydrolysed peptide bonds in the hamster and mouse zonae. For collagenase I to hydrolyse mouse zona protein, it would have to hydrolyse zona glycoprotein $\mathrm{Zp}-1$, as the zona glycoproteins $\mathrm{Zp}-2$ and $\mathrm{Zp}-3$ lack susceptible bonds for this enzyme (Kinlock et al., 1988; Ringuette et al., 1988; Liang et al., 1990; Lunsford et al., 1990). While it is not clear which of the active agents are involved in zona dissolution, the data suggest that commercial collagenase preparations contain proteases that gently remove the mouse and hamster zonae pellucidae without damaging the oolemma. As the types and concentrations of the contaminating proteases vary from lot to lot, even among the products of the same manufacturer, we will have to determine which of the contaminating proteases are the zona-dissolving enzymes.

As confirmed by the present study, the mouse oolemma is much more sensitive to protease than is the hamster oolemma. A 30 -min treatment of mouse oolemma with $0.1 \%$ trypsin or chymotrypsin renders it almost totally incapable of fusing with spermatozoa (Boldt et al., 1988). The same treatment has little or no effect on the fusibility of the hamster oolemma (Hirao \& Yanagimachi, 1978). The reason for this marked difference is unknown, but the peripheral glycoproteins, which are vulnerable to proteolytic digestion, may play a crucial role in sperm-oocyte fusion in mice. In hamsters, on the contrary, glycolipids, mucin-like glycoproteins or integral glycoproteins, which are relatively insensitive to proteolytic digestion, may play a leading role in this fusion process.

This study was supported by grants from the National Institute of Child Health and Human Development (HD-03402) and United States Department of Agriculture (88-37240-3969 UAU). 
We thank D. P. Wolf of the Oregon Regional Primate Research Center for invaluable suggestions during the course of this study. We also thank C. Oser for assistance in the preparation of the manuscript.

\section{References}

Boldt, J. \& Wolf, D.P. (1986) An improved method for isolation of fertile zona-free mouse eggs. Gamete Res. $13,213-222$.

Boldt, J., Hower, A.M. \& Preble, J. (1988) Enzymatic alteration of the ability of mouse egg plasma membrane to interact with sperm. Biol. Reprod. 39, 19-27.

Boldt, J., Gunter, L.E. \& Howe, A.H. (1989) Characterization of cell surface polypeptides of unfertilized, fertilized and protease-treated zona-free mouse eggs. Gamete Res. 23, 91-101.

Gwatkin, R.B.L., Anderson, O.F. \& Williams, D.T. (1980) Large scale isolation of bovine and pig zonae pellucidae: chemical, immunological, and receptor properties. Gamete Res. 3, 217-231.

Hedrick, J.L. \& Wardrip, N.J. (1986) Proteolysis by collagenase preparations alters the macromolecular composition of the porcine zona pellucida. Biol. Reprod. 35, 677-682.

Hirao, Y. \& Yanagimachi, R. (1978) Effects of various enzymes on the ability of hamster egg plasma membranes to fuse with spermatozoa. Gamete Res. I, $3-12$.

Inoue, M. \& Wolf, D.P. (1975) Fertilization-associated changes in the murine zona pellucida: A time sequence study. Biol. Reprod. 13, 546-551.

Kamiguchi, Y. \& Mikamo, K. (1986) An improved, efficient method for analyzing human sperm chromosome using zona-free hamster ova. Am. J. Hum. Genet. 38, $724-740$.

Kinlock, R.A., Roller, R.J., Fimiani, C.M., Wassarman, D.A. \& Wassarman, P.M. (1988) Primary structure of the mouse sperm receptor polypeptide determined by genomic cloning. Proc. Natl Acad. Sci. USA 85, 6409-6413.

Kojima, K., Kinoshita, H., Kato, T., Nagatsu, T. \& Sakakibara, S. (1979) A new and highly sensitive fluorescence assay for collagenase-like peptidase activity. Analyt. Biochem. 110, 43-50.

Kopf, G.S. \& Gerton, G.L. (1991) The mammalian sperm acrosome and acrosome reaction. In Elements of
Mammalian Fertilization, pp. 153-203. Ed. P. M. Wassarman. CRC Press, Boca Raton, Florida.

Liang, L.F., Chamow, S. M. \& Dean, J. (1990) Oocyte expression of $\mathrm{Zp}-2$ : Development regulation of the zona pellucida genes. Mol. Cell Biol. 10, 1507-1525.

Lunsford, R., Jenkins, N.A., Kozak, C.A., Liang, L.F., Silan, C.M., Copeland, N.G. \& Dean, J. (1990) Genomic mapping of murine $\mathrm{Zp}-2$ and $\mathrm{Zp}-3$, two oocyte-specific loci encoding zonae pellucida proteins. Genomics 6, 184-187.

Ringuette, M.J., Chamberlin, M.E., Baur, A.W., Sobieski, D.A. \& Dean, J. (1988) Molecular analysis of cDNA coding for ZP3, a sperm binding protein of the mouse zona pellucida. Devl Biol. 127, 287-295.

Tesarik, J. \& Kopecny, V. (1989) Development of human male pronucleus: Ultrastructure and timing. Gamete Res. 24, 135-149.

Thadani, V. (1982) Mice produced from eggs fertilized in vitro at a very low sperm: egg ratio. J. exp. Zool. 219, 277-283.

Urch, U.A. (1991) Biochemistry and function of acrosin. In Elements of Mammalian Fertilization, pp. 233-248. Ed. P. M. Wassarman. CRC Press, Boca Raton, Florida.

Wassarman, P. M. (1987) The biology and chemistry of fertilization. Science, $N Y$ 335, 553-560.

Wolf, D.P., Inoue, M. \& Stark, R.A. (1976) Penetration of zona-free mouse ova. Biol. Reprod. 15, 213-221.

Yanagimachi, R. (1988a) Mammalian fertilization. In Physiology of Reproduction, pp. 135-185. Eds E. Knobil \& J.D. Neil. Raven Press, New York.

Yanagimachi, R. (1988b) Sperm-egg fusion. In Current Topics in Membranes and Transport, vol. 32, pp. 343. Eds N. Duzgunes \& F. Bronner. Academic Press, Orlando, Florida.

Zuccotti, M., Yanagimachi, R. \& Yanagimachi, H. (1991) The ability of hamster oolemma to fuse with spermatozoa: its acquisition during oogenesis and loss after fertilization. Development 112, 143-152.

Received 4 January 1991 